\title{
Editorial
}

\section{Fulfilling its Promise - Information Polity as an International Journal}

As Editor, I am delighted that this journal continues to fulfil both its promise and its objectives. As with any new venture there is some uncertainty about whether it will succeed. In the case of an academic journal a key measure of success is the number of manuscripts received from prospective authors. In its first two years the journal has proved itself in this respect, receiving more articles than it can carry and at a pace that is enabling it to become a regular publication, gradually getting to a position of publishing four editions on an annual cycle. A second key measure of success lies in the quality of the published articles. The journal adheres to strong quality standards and procedures and will, of course, continue to do so. I am constantly reassured by the positive and constructive comments that come back to me from reviewers (as well as by the speed with which they turn them around!).

Another measure of success, which is fully exemplified by the content of this double issue, is the internationalisation of the journal. Many journals lay claim to being international though their content may well suggest otherwise. However, throughout the short life of Information Polity I have been able to publish contributions from authors working in many different countries. This double issue is a very good example of this international scholarship. Of the seven substantive articles in this edition, two are written by Dutch colleagues and two by British academics. The three remaining articles are written by French, Slovenian and Swedish colleagues. There is a truly international gathering going on under the masthead of Information Polity. Also, two of the articles in this double edition are 'country studies', something for which I called at the outset of the journal. Thus the articles on French and Slovenian e-government in these current issues provide further contributions to this growing body of articles that will come to form baselines and benchmarks as scholars and public policy makers come to write their own country studies in the future.

This edition starts with an article on virtual organisation written by Victor Bekkers. For many years now scholars in our field and more broadly have written about the emergence of virtual organisations, though little in the way of strong empirical evidence or analysis has been produced. In his article Bekkers begins to provide both the evidence and analysis upon which this concept of the virtual organisation can be better understood, evaluated and contested. There is a growing understanding amongst government and business practitioners that full pay-off from the massive investments made in ICT will come only when work practices and organisational forms are re-cast alongside the introduction of new information and communication systems. Bekkers analysis will work well alongside this understanding. His typology of five virtual organisations is a valuable contribution. The federal, concentric, platform, portal and web forms of virtual organisations provide a set of archetypes against which measures of success in government 'modernisation' programmes can be set.

The articles by Wagenaar and Soeparman and Alcaud and Lakel provide new evidence of value to those interested in the nature of change and continuity in administrative systems. As with so many other 
studies, they point to the likely failures of heroic approaches to administrative change that are still so frequently to be found, particularly in the advice given and consultancy undertaken for governments and their agencies. Wagenaar and Soeparman are extremely tentative in their conclusions about the possibilities for deep reform of the Dutch police system, pointing out the main pillars of the system that hold it in place. Whilst reform might appear to shift the edifice of the system by challenging one of the pillars, it will not do so completely unless all of these support systems are challenged and reformed simultaneously. Alcaud and Lakel look at French administrative modernisation at the level of the State rather than at the functional level as with Wagenaar and Soeparman. They too point up the immense obstacles that lie of the track of change, best summarised by a ringing quotation to be found in their concluding remarks:

"Part of future organization is set in present day code. That is why the State will have a pressing need to find information architects because the architecture of information systems now will be the architecture of the administration in the future."

Information Polity will welcome accounts of successful administrative and organisational change. To this point in time they have not been forthcoming.

The article that follows provides a further country study, that of Slovenia. Written by Mirko Vintar and his colleagues at Ljubljana University the article takes a critical look at progress towards e-government realisation in Slovenia. It does so by adducing what has become more or less standard data on progress towards e-government as provided through categories developed by Cap-Gemini, arguing that Slovenia is making good progress when benchmarked against both other EU Accession countries and the older EU. However, their analysis is not without sharp criticism. In conclusion they say:

“... action plans and strategies for the Slovenian e-government are well crafted and in line with the speedy developments of IT and public administration around the world. Also, it is fair to say that there are a few examples that are at the forefront of such systems in Europe. Elsewhere, however, the picture differs. There are some delays in the informatisation of administrative districts and municipalities and the courts have poor IT support. The services provided are prevalently information services, thus preserving the organisational structure of old public administration, based on paper work".

Once more they demonstrate, as with the two previous papers, the difficulties of delivering the organisational changes upon which 'deep e-government' can be realised.

The article by Higgs and Turner places e-government into a local authority setting and like the previous articles it reaches striking conclusions about the necessity of 'strategic grip' if full advantage of new systems (in this case Geographical Information Systems (GIS)) is to be realised. The authors recognise that local authorities are now playing out quite a different role than previously, notably in that they have become much less involved with direct service provision and much more at the centre of a "web of governance' providing strategy, monitoring and measurement mechanisms to enable the delivery of services through partnerships. It is within this new arena of governance that the ability to exchange information both internally, across traditional institutional boundaries, and externally with the citizen will be crucial, they argue. Additionally, because "a significant proportion of information managed by local authorities has a locational element, usually in the form of an address, an administrative or statistical area or a geographically defined region, ... the management of such information is an important element of the delivery of electronic government ...". GIS, if well managed, thus has the potential to become a powerful integrating tool for e-government.

The papers from Agneta Ranerup and Ulrika Josefsson and Eleanor Burt and John Taylor are deeply complementary. Each of them addresses new questions that are raised by the increasing introduction 
into the governmental and democratic polity of 'intermediaries' that either aim to add consumerist value to e-government service delivery and/or to deliver those services independently of government. In the Swedish case the authors persuasively argue that the introduction of new electronic intermediaries between citizens and the public sector is providing citizens with new "capacities to act".

The identified capacities to act are characterised as means for citizens to use and produce information, to develop specific and general knowledge, as well as to act on an individual and a collective basis. We conclude that the intermediaries are sophisticated instruments in a learning process that support the citizens' development into active consumers of public services.

In the British case these new intermediaries are seen as enabling the governmental potential for " 'joined-up', citizen-centric services that are 'bundled' together in ways that reduce the cost and risk to government, whilst making the services considerably more accessible to citizens". Burt and Taylor place their analysis onto a macro footing too, arguing that we are witnessing profound shifts in the system of power and influence within the polity as newly engaged and informationally enriched voluntary organisations take on the enhanced roles that intermediation legitimates.

J.A. Taylor

Oxford Internet Institute

University of Oxford

April, 2004 